\title{
APPLICATION OF DESIGN SPACE OPTIMIZATION STRATEGY TO THE DEVELOPMENT OF LC METHODS FOR SIMULTANEOUS ANALYSIS OF 18 ANTIRETROVIRAL MEDICINES AND 4 MAJOR EXCIPIENTS USED IN VARIOUS PHARMACEUTICAL FORMULATIONS
}

\author{
V. Habyalimana $^{1,2}$, J. K. Mbinze ${ }^{3}$, A. Yemoa ${ }^{4}$, C. Waffo ${ }^{1}$, D. Tidiane ${ }^{5}$, N. Kalenda \\ Tshilombo $^{1,3}$, J. L. Kadima Ntokamunda ${ }^{6}$, P. Lebrun ${ }^{7}$, Ph. Hubert ${ }^{1}$, R.D. Marini ${ }^{1}$ \\ ${ }^{1}$ University of Liege (ULg), Department of Pharmacy, CIRM, Laboratory of Analytical Chemistry, \\ Quartier Hôpital, 15 Avenue Hippocrate, B36, B-4000 Liège, Belgium. \\ ${ }^{2}$ Rwanda Biomedical Center/Medical Procurement and Production Division, Kigali, Rwanda \\ ${ }^{3}$ University of Kinshasa, Faculty of Pharmaceutical Sciences, Laboratory of Drug Analysis, Kinshasa, \\ Democratic Republic of Congo \\ ${ }^{4}$ Université d'Abomey Calavi, Ecole de Pharmacie, Faculté des Sciences de la Santé, Laboratoire de \\ Chimie Analytique et Analyse des Médicaments (LCAM), Cotonou, Bénin \\ ${ }^{5}$ Université des Sciences, des Techniques et des Technologies de Bamako ; Faculté de Pharmacie, \\ Département Science du Médicament, Mali \\ ${ }^{6}$ University of Rwanda, School of Medicine and Pharmacy, Butare, Rwanda \\ ${ }^{7}$ Arlenda S.A., Saint Georges sur Meuse and Louvain-La-Neuve, Belgium.
}

\section{Introduction}

HIV/AIDS remains one of the world's most significant public health challenges in low- and middle-income countries: about 36.7 million people living with HIV, 2.1 million people becoming newly infected, Sub-Saharan Africa being the most affected region with 25.6 million people living with HIV in $2015^{[1,2]}$. ARVs are not spared from counterfeiting due to their substantial high unit costs, long term and sustained demand. Several case reports of counterfeit ARVs are published ${ }^{[3-5]}$ among which the WHO alert in 2003 towards a product called 'Ginovir 3D' marketed in Ivory Coast as a triple ARV combination. It was containing only one of the three labeled active ingredients and a non-declared other ARV agent ${ }^{[3]}$. As the antiretroviral therapy (ART) constitutes a growing pharmaceutical research field combining several ARV medicines to maximally suppress the HIV virus and stop the progression of HIV disease, there is need of disposing rapid and efficient analytical methods to serve at different stages of drug development to ensure quality, safety and efficacy. Unfortunately this pertaining demand is in contrast with few existing monographs dedicated to the analysis of multiple ARV combinations including those already marketed.

\section{Purpose / Goals}

We targeted the development of LC methods that can analyze 18 antiretroviral medicines namely abacavir (ABC), didanosine (ddI), efavirenz (EFV), emtricitabine (FTC), indinavir (IDV), lamivudine (3TC), lopinavir (LPV), nelfinavir (NFV), nevirapine (NVP), raltegravir (RAL), ritonavir (RTV), saquinavir (SQV), stavudine (d4T), tenofovir (TDF), zidovudine (ZDV or AZT), atazanavir (ATZ), darunavir (DRV), etravirine (ETV). This group includes 4 major excipients mostly used in oral suspension formulations: butylated hydroxytoluene (BHA), butylated hydroxyanisole (BHT), nipagine ( $\mathrm{NpG})$, and nipasol $(\mathrm{NpS})$.

\section{Materials and Methods}

The methods were developed through design of experiment and design space (DoE/DS) methodology ${ }^{[6-8]}$. Focusing on rapid and affordable aspects, a short column (RP18, $100 \mathrm{~mm} x$ $4.6 \mathrm{~mm}$ (ID), $3.5 \mu \mathrm{m}(\mathrm{dp})$ ) and low cost organic solvent (methanol) were used in gradient mode with $10 \mathrm{mM}$ ammonium dihydrogen carbonate buffer or ammonium formate buffer as mobile phase. Prior to the use in routine analyses, one method was validated according to the total error approach taking into account the accuracy profile as decision tool ${ }^{[9]}$.

\section{$\underline{\text { Results and Discussion }}$}


The screening method was predicted thanks to Monte Carlo simulations for the analysis of 18 compounds and 4 excipients above listed. The column temperature optimized at $35^{\circ} \mathrm{C}$ and gradient time at $21.3 \mathrm{~min}$ allowed monitoring these compounds at $210 \mathrm{~nm}$. Another prediction was carried out for fixed dose combination of EFV/FTC/TDF. The validation results for that combination in tablet formulations was satisfying in terms of selectivity/specificity, trueness, precision, accuracy, linearity and dozing range. Two samples coded A and B were analyzed (see results below):

\begin{tabular}{|c|c|c|c|}
\hline \multirow{2}{*}{ Samples } & $\begin{array}{c}\text { EFV } \\
\text { Claimed content } \\
\text { (Found content in \%) }\end{array}$ & $\begin{array}{c}\text { FTC } \\
\text { Claimed content } \\
\text { (Found content in \%) }\end{array}$ & $\begin{array}{c}\text { TDF } \\
\text { Claimed content } \\
\text { (Found content in \%) }\end{array}$ \\
\hline Code A & $600 \mathrm{mg}$ & $200 \mathrm{mg}$ & $300 \mathrm{mg}$ \\
\cline { 2 - 4 } & $100.3 \pm 1.04 \%$ & $80.2 \pm 0.78 \%$ & $84.8 \pm 1.17 \%$ \\
\hline Code B & - & $200 \mathrm{mg}$ & $300 \mathrm{mg}$ \\
\cline { 2 - 4 } & - & $93.1 \pm 1.74 \%$ & $91.5 \pm 1.40 \%$ \\
\hline
\end{tabular}

\section{Conclusion}

We were able to separate 18 ARV compounds and 4 major preservatives thanks to DoE-DS. The method was satisfying to quantify three ARV in tablet samples. The DoE/DS database can serve in the prediction of other optimal conditions for any fixed-dose combination.

\section{References}

[1] WHO, 10 facts on HIV/AIDS (updated July 2016): http://www.who.int/features/factfiles/hiv/en/, accessed on August 31, 2016

[2] WHO, HIV/AIDS Fact sheet (updated July 2016):

http://www.who.int/mediacentre/factsheets/fs360/en/, accessed on August 31, 2016

[3] World Health Organization (WHO): Counterfeit triple antiretroviral combination product (Ginovir 3D) detected in Cote d'Ivoire: Information Exchange System Alert No 110. Geneva: WHO; 2003. QSM/MC/IEA.110

[4] Ahmad K: Antidepressants are sold as antiretrovirals in DR Congo, Lancet 2004, 363, 713.

[5] http://www.irinnews.org/report/94012/kenya-government-grapples-counterfeit-arvs; accessed on August $24^{\text {th }}, 2016$

[6] http://dx.doi.org/10.1016/j.chroma.2011.05.102

[7] http://dx.doi.org/10.1016/j.chroma.2012.09.038

[8] http://dx.doi.org/10.1016/j.jpba.2013.06.036

[9] http://dx.doi.org/10.1016/j.jpba.2004.07.027 